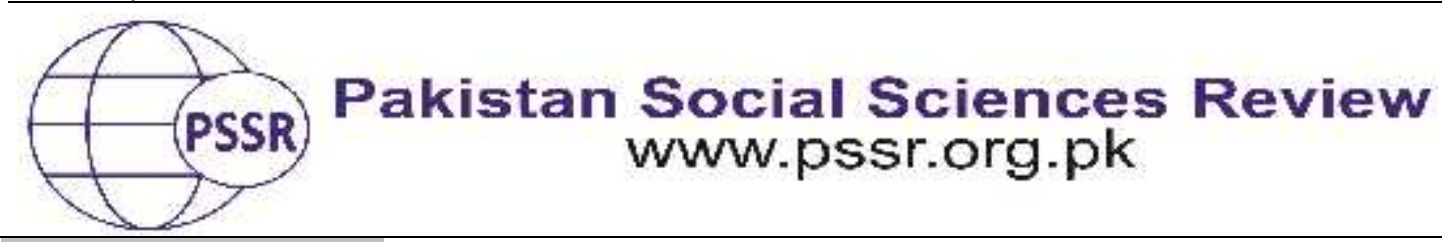

RESEARCH PAPER

\title{
Challenges of Militancy and Religious Extremism to National Security of Pakistan: An Analysis
}

Dr. Ramzan Shahid ${ }^{1}$ Shehzada Afzal ${ }^{2}$ Zahid Yaqub ${ }^{3}$

1. Assistant Professor, Department of Political Science and International Relations, University of Gujrat, Punjab, Pakistan

2. PhDScholar,Department of International Relations QAU, Islamabad, Pakistan

3. PhD Scholar, Department of International Relations, University of Karachi, Sindh, Pakistan

\begin{tabular}{|c|c|}
\hline PAP & $\mathrm{ACT}$ \\
\hline $\operatorname{Rec}$ & has been \\
\hline & 1 Secur \\
\hline & was $\mathrm{r}$ \\
\hline & domi \\
\hline $\begin{array}{l}\text { Or } \\
\text { Sep }\end{array}$ & \\
\hline Key & al \\
\hline & role \\
\hline & ns \\
\hline & ous \\
\hline & alle \\
\hline Cor & \\
\hline $\mathbf{A u}$ & of \\
\hline & urity as well as on ext \\
\hline
\end{tabular}

\section{Introduction}

National security is a concept in which institutions of Sovereign state provide Protection to its citizens against all kinds of internal and external threats by using its all resources of Military, Political, Diplomatic and Economic Power(Chishti, Pakistan's National Security: An Analytical Study, 2014).The concept of National Security mostly developed in United States after World War-II. Initially the term "National Security" was used as the security of a state, by using military resources for territorial integrity, sovereignty and protection of its territory from external threats. This term was mostly understood as territorial security of state(Miller, 2001). Rapidly changing international politics and relations among the Nations forced policy makers to think out of the box for securing a Nation from all kinds of crises 
and threats. It needs other form of security besides military power, which can provide stability to state in challenging or crisis situation and which has direct influence on state security so it was really necessary for every state to provide economic security, political security, environmental security, and social security to its citizens(Paleri, 2008). Political structure, Economic conditions, Environment, Geography, Social behavior, Military capabilities, Technology, Manpower, Natural resources, Nature of relations with other nations, Foreign policy objectives and legitimate interests collectively form the National Security policy for any country(Romm, 1993).

\section{What is National Security?}

There is no single universally accepted definition of National Security. Every state may not have same meanings of National Security because of its various factors involved in National Security which some country values more too specific component of National Security but other consider it as less important(Paleri, 2008).

Scholars of International Relations defined "National Security" during the different periods of time which help us to understand the concept of National Security. Walter Lippmann (1943) depicts National Security as "A nation has security when it does not have to sacrifice its legitimate interests to avoid war, and is able, if challenged, to maintain them by war"(Romm, 1993, p. 05). While Harold Lasswell (1950) has a distinct view about National Security considering "The distinctive sense of national security means freedom from foreign dictation with balancing handling of arms, diplomacy and economy correlation of domestic, and foreign policy " (Paleri, 2008). Another ScholarArnold Wolfers (1962) said that "National security meaning different thing to different people. It objectively means, the absence of threat and absence of fear that such values will be attacked" (Romm, 1993, p. 05). International Encyclopedia of Social Sciences (1968) defined National Security as "International Encyclopedia of Social Sciences defines National security as the ability of State to safeguard its internal values from all External threats" (Romm, 1993).National Defense College of India (1996) portrays it "National security is an appropriate and aggressive blend of political resilience and maturity, human resources, economic structure and capacity, technological competence, industrial base and availability of natural resources and finally the military might" (Paleri, 2008, p. 54).

Above definitions reveal that National Security is ability of any state to deal with all kind of internal and external challenges. National security not only include territorial security of the state but It has number of elements which form National Security including Military security, Political Security, Economic security, Environmental security, Energy and power resources security, Border security, and cyber security etc. These elements are interconnected; one element can harm others and one element would have more value than others. Every state has different meanings of the National Security because some countries value more to specific components of National Security but other considered it as less important. For 
example, Asian countries consider border security and military might a key element to determine National Security policy whereas European countries value more to Economic Security or trade with other countries rather than focusing on border security but as a whole, all components are necessary to form National Security. In formulation of National Security policy of any country geography, technology, internal conditions, nature of relations with other countries and resources play very important role (Paleri, 2008).

Over the years concept of National Security has considerably altered. After 9/11 attacks, National Security term is using even in broader meaning. It's not only covers the wide range of conventional threat from other states but also possess Nonstate actors such as organizations, Multinational corporations and Nongovernmental organizations, ethnic groups and intelligence agencies of other countries which pose some kind of threat to state and its citizens. It is range to maintain requirements of the state security through using economic, diplomatic, political and military power(Chishti, 2014).

\section{Pakistan's National Security: Recurring Paradigm Change}

Pakistan has facing challenge of National Security since 1947. Pakistan is only country in the world which came into existence on ideological bases. Two nation theory and Islamic ideology played a decisive role in creation of new state. Pakistan's Ideology is based on peaceful relations with all the countries of the world. It does not cherish any aggressive design against any county. Its foreign policy is based on friendliness and good will toward all the nations. When Pakistan came into being it had faced different kind of challenges. Initially the nature of the problems was mostly social, financial and administrative but most dominant concern always remained security of state and its citizens. It faced security threats just after independence from India as it was not ready to accept Pakistan as an independent state. The agenda of its policy makers was mostly to destabilize Pakistan in every sector. Afghanistan and Iran had also issues on the boundaries of Pakistan. Specially Afghanistan had concern on Durand line issue and also had claim on part of KPK. The main reason of conflict between two neighboring country is Kashmir dispute. Policy makers of Pakistan had to pursue a policy and develop strategic culture to counter external threat mostly from India. Security concerns, geographical location and Ideology played an important role in the formulation of National Security policy. In fact Ideology and Security are two dominant factors to give directions to its National Security policy (Burke, 1973).

\section{7-53: External Threats}

Initially National Security policy was largely influenced by its nature of relations in a region with neighboring countries particularly with India. The early years of independence were subjugated with perturbing relations with India and Afghanistan. At one hand as a new born state it had to deal with internal problems and on other hand it had to deal with external threats. Most of the problems 
developed with India were due to the patrician process set out as result of $3^{\text {rd }}$ June 1947 plan. These disputes were further enhanced and developed into first Kashmir war in 1947-48. Since then Kashmir was a core issue of dispute among both countries. Disputes were further enhanced in financial distribution, armed distribution and over river water problem. (Burke, 1973) So the foundation of enmity was started to develop between two nations right from its formation as India was not ready to accept Pakistan as an independence state. Since then India had left no stone unturned to destabilize Pakistan. This negative approach had played a role in the development of distrust, hostility, hate, and enmity between India-Pakistan relations.

As well as since beginning, relations with Afghanistan were not smooth. Afghanistan did not recognize Pakistan as a Sovereign state owing to its divergent claims over NWFP (Now Khyber Pakhtunkhwa) and Baluchistan. Afghanistan refused to recognize Pakistan's sovereignty over these provinces. India also indorsed Afghanistan inapt claims over Pakistani territory. USSR also provided similar support to Afghanistan in 1950 (Rizvi, 2004).

\section{3-62: Alignment with the West}

These peripheral security threats forced policy makers to reorganize its military capabilities and enhance defense capabilities to counter these extortions. Pakistan was keen to develop relations with advanced countries due to two reasons; to enhance its defense capabilities and for economic revival. (Saif, 2007) USSR's approach was different towards Pakistan as compared with India. Soviet Union obeisance behavior and sympathy toward India and her slant to favor Afghanistan over NWFP (KPK) issue enforced Pakistani policy makers towards West. Defense Agreements like South East Asia Treaty Organization (SENTO) and Central Treaty Organization CENTO (1953-54) were signed with the USA to counter these threats (Malik I. H., 2008). The main objective of SENTO was basically to contain communists but Pakistan was involved in alignment with west to get help in the case of aggression from India and to get conventional weapons to modernize its armed forces. As a result of these agreements Pakistan received military assistant, conventional weapons and other support. This certainly helped Pakistan to organize and equip her military with latest technology and military warfare techniques (Rizvi, 2006).

\section{3-71: Rethinking Alignment Policy}

USSR devised strong relations with India during this period. It also opposed Pakistan over Kashmir issue and shaped strong strategic relations with India. In this period Pakistan's relations with Muslim countries also agonized. Most of the Middle Eastern countries had concerns over Pakistan pro-west policies. Despite these mutual agreements, USA was acute to foster its relations with India to peruse its agenda in the region which was a greatapprehension for Pakistan. India is three timeslarger than Pakistan and suit more to fulfill US interests in this region. USA and 
western countries provided military equipment and aid to India during Sino-India border war in 1962. Actually USA was pursing her agenda in this region. Despite Pakistan had shown deep concerns and tried to convince US that India will use these weapons against Pakistan. Moreover USA and western alliance failed to provide any kind of collective security arrangements and measures during the course of war with India in 1965 and 1971 (Shah \& Riaz, 2013).

\section{2-79: Nonalignment}

Disappointed response from USA and west forced Pakistani policy makers to review their policy. In the period of 1972 to 1979, Pakistan's policy was more focused to establish good relations with communist countries. Its relations with Muslim countries including Afghanistan were also improved. Pakistan withdrew from SEATO in 1972 and adopted Non-Alignment policy. Pakistan adopted independent policy during the period of 1972 to 1979 in its relations with other countries.

\section{0-90: Soviet-Afghan war and Partnership with the United States}

Although Pak-Afghan relations were not very ideal before 1979 but still security threat from western border was not considered as alarming before Soviet Union invaded Afghanistan in December 1979. Here was a huge twist in Pakistan's policy towards its western borders. Since then Pakistan and Afghanistan relations have experienced many ups and downs (Cheema, 2006). Pakistan's relations with Soviet Union remained always in great strain; Afghanistan was only a buffer zone between the two states. Feeling presence of soviet troops in neighborhood not only threaten Pakistan's external security but also motivated pro-soviet elements working against the state in NWFP and Baluchistan. Pakistan's administration observed this development as attack on the sovereignty of non-allied Muslim state and declared this move as direct threat to its own national security. Pakistan demanded immediate withdrawal of soviet troops from Afghanistan. Pakistan's policy makers decided to support Afghan groups who were fighting against Soviet army. Basic objective was to support Afghan Mujahedin to dislodge and to stop further movement of soviet troops. Pakistan accommodated more than 3 million Afghan refugees and allowed Afghan mujahedeen to freely operate in its territory near afghan border (Ali, 2001).

Pak-US relations were at lowest level before soviet-afghan war in1979. US offered its full support and economic assistance to Pakistan during this war. US administration regarded this development as an opportunity to defeat their rival through proxy war. USA and west block provided her full support to Pakistan during that war. Pakistan Government and US department of state worked together during this war. Close relations were developed between ISI (Inter-services Intelligence) and CIA (central Investigation Agency). Pakistan's relations with Muslim countries especially with Saudi Arabiawere strengthened. Saudi Arabia provided its full support during Afghan Jihad. US provided weapons, Military training and economic assistance to Afghan groups and called them as "Afghan 
Mujahedeen". USA also encouraged Arab and western states to participate in this war by supporting Afghan mujahedeen's struggle against Soviet Union (Rizvi, 2006).

Pakistan and US alliance successfully refuted the Soviet threat. With the corporation of USA and Western allies Pakistan not only effectively stopped the soviet troop's forward movement but also provided all possible help to Afghan Mujahedeen to counter soviet army. At last effective counterstrike forced Soviet Union to withdrawal from Afghanistan.Pakistan, Afghanistan, and United States signed the Geneva Accords with the Soviet Union, which opened the way of peaceful resolution of the Afghanistan problem. Soviet Union initiated withdrawal as a result of that agreement on May 15, 1988 and that withdrawal was completed on February 1989 (Rizvi, 2006).

\section{1-2001: Post Cold War Era}

After withdrawal of soviet troops from Afghanistan, USA totally changed its policy and left Pakistan and Afghanistan to their own fate. Pakistan had to deal with serious kind of challenges at one hand as well as it had to deal with more than three million refugees on Pak-afghan border. US after effectively completing its objectives in Afghanistan stopped all kinds of aid to Pakistan including military assistance and reduced economic assistance for refugees realizing Pakistan its lesser strategic importance. Pakistan had to deal with intra-Afghan conflict which later on malformed into a civil war. Due to Afghanistan internal situation it was clear that refugee problem will remain unsolved for long time.In that era Pakistan's relations with India were also very cruel due to Kashmir insurgency and Indian ruthless aggression against Kashmiris. That diverted Pakistan attention toward eastern border. International politics was also vibrant during that period. Soviet withdrawal from Afghanistan, end of cold war in 1989 and break up of Soviet Union in 1991 provided opportunity to USA to lead the world politics as a superpower in the absence of competing power. USA and west completely ignored the Afghanistan while Pakistan had to stay in the region. It could not afford to open two fronts at a time that was one of the main reasonsthat Pakistan supported the Taliban regime during 1996 to 2001. Pakistani policy makers regarded friendly relations with Afghanistan as providing strategic depth to Pakistan against India.

\section{1 to onward: War on Terrorism}

9/11 attacks on world Trade center and Pentagon had long term implications on international system and International politics. International community view terrorism as a global threat. World community decided to adopt effective actions against Non-state actors and terrorist elements. USA administration accused AlQaeda and her leader Osama bin laden based in Afghanistan under Taliban regime was behind that attacks. USA successfully convinced international community to launch military operation against them to eliminate Al-Qaeda. Due to the friendly relations with Taliban and long border with Afghanistan once again Pakistan became focused of world politics. Pakistan took a U-turn on its Afghan policy and 
decided to go with International community to act as frontline state in the war on terrorism. After that Pakistan faced different kinds of internal and external challenges to its National Security in the form of Militancy, Extremism and Terrorism.

\section{Narrative of Militancy and Religious Extremism in Pakistan}

Jihad, Islamic Fundamentalism and Muslim Ummah were the basis behind building a narrative to fight against communism in Afghanistan. Earlier in the history of country the nature of threat was mostly external and Pakistan had to defend its territory from India and its focus remained on eastern border. But the situation entirely changed after Pakistan's Soviet invasion of Afghanistan and Pakistan's active role in Afghan Jihad (Soviet-Afghan war).For this purpose promotion of Militancy and Extremism were the major factor for building of Jihadi narrative.The main factors or reasons which explain the genesis of Extremism and Militancy in Pakistan and building of Jihadi narrative are as follows.

\section{Afghan Jihad 1979}

On 26 December 1979, Soviet forces invaded Afghanistan. This antagonistic military move shocked the whole world. The US led Western block viewed that invasion as biggest threat to American interests in the region. The message was sent to the world that communist wanted to control world economy to occupy oil resources of Gulf countries. US administration during carter regime decided to setup rapid deployment force to stop the communist forward movement(Javaid \& Fatima, 2013).Soviet invasion in Afghanistan brought super powers face to face in this region which gave Pakistan opportunity to play role in regional and global politics. United States created Mujahedeen to achieve their objectives in this region. Hillary Clinton confessing this role in creating the Mujahedeen in the Eighties said in an interview that

"We have strolled away from Pakistan and Afghanistan in the past....we had actually helped to create the problem.we are fighting because when the USSR invaded Afghanistan...we had a wonderful idea to come to Pakistan and form a force of mujahedeen, armed them....to go after the Soviets inside Afghanistan, and we were successful. Soviets left Afghanistan and we said goodbye leaving these people who were obsessive and armed, in Afghanistan and Pakistan." (Hillary Clinton: 'It Would Be a Mistake' to Walk Away from Pakistan, 2010)(Azam, 2014).

The soviet invasion was considered as a direct threat to Pakistan National Security. Although Pakistan successfully achieved its objective to use force of Mujahedeen but Pakistan was actually playing with fire. These groups of mujahedeen were not only fighting with soviets but they had specific fundamental ideology which gradually developed roots in Afghanistan and some parts of Pakistan. Training camps, madrassa culture and Islamic political parties come to 
forefront during Afghan Jihad. More than 100000 foreigner Muslims directly participated by Afghan Jihad (Hussain , 2007).

Pakistani religious parties and groups were vocal before Afghan jihad but it had not element of militancy in them. Afghan war actually introduced militant culture. Mullah-Military alliance which was fully supported by American think tanks through CIA (Central Intelligence Agency) with the help of ISI (Inter-Services Intelligence) to achieve was built to set goals. This alliance was the binging of Militancy in Pakistan. These groups were given specific agenda with all kinds of resources including money, power, and weapons and training facilities etc. Pakistani authorities also provided access to some Arab countries to specific sectarian parties (Weinbaum, 1991).

\section{Policies of General Zia-Ul-Haq}

Actually Afghan Jihad and General Zia are intermingled with each other. General Zia era is deliberated the most dynamic phase of history in terms of genesis of extremism in Pakistan. Scholars across the board agree that the military ruler perused some policies which provided grounds and settings for radical and extremist element in Pakistani society. His Policies spread the seeds of extremism and laid the foundation of militant culture in Pakistan. In his regime fundamentalist groups not only acquired power and resources but also provided a facility to use Pakistani territory (adjacent to Afghan border) as a training camp against Soviet Union during Afghan Jihad. In the past military role was limited to border security and was considered to ultimate guarantor of geographical territory and internal security of the country but General Zia expanded military role as the protector of Pakistan's ideological front as well. He used religion as a main tool to pursue his policies. He laid the foundation for religiously dominated National Security doctrine (Hussain, 2007).

Zia Islamization program negatively affected Pakistani society. The Sunni religious parties JUI and JUP became active against Shai minority and demanded to establish Pakistan as a Sunni Islamic state as Iran declared as Shia state. Shia also stated the movement known as Tehrik-i-Nifaz-Fiqh-Jafrriya to protect their rights (Abbas, 2002).

\section{Saudi - Iran Rivalry}

International and regional politics also favored to develop extremism and sectarianism in Pakistan. External events like Iranian revolution, Iran - Iraq war, and Saudi-Iran struggle for the regional leadership negatively affected Pakistan. The Iranian revolution of 1979 motivated and politically activated Shia minority to play a part in Pakistani politics. Saudi- Iran proxy war also came to Pakistan through both countries funding their favorite groups to reinforce their version of Islam in Pakistan. Iranian embassies started funding Shia organizations including Tehreek-iNifaz-i-Fiqh-i-Jafaria and Shia alliance organization. Iran also offered Scholarships in large numbers for Pakistani students to study in Iran. Saudi Arabia was concerned 
about expansion of Shi'ism in any other Muslim country. They started funding to Pakistani Government and domestic religious political parties with the agenda to enforce Wahhabi brand of Islam in Pakistan (Abbas, 2002).

This not only nurtured sectarian conflict but also developed the extremist elements in Pakistani Society. These foundations gradually divided Pakistani society into different groups, classes and sects which urbanized hate among the different clusters which eventually lead society toward militancy and extremism.

\section{Narrative of Militancy and Religious Extremism in Pakistan}

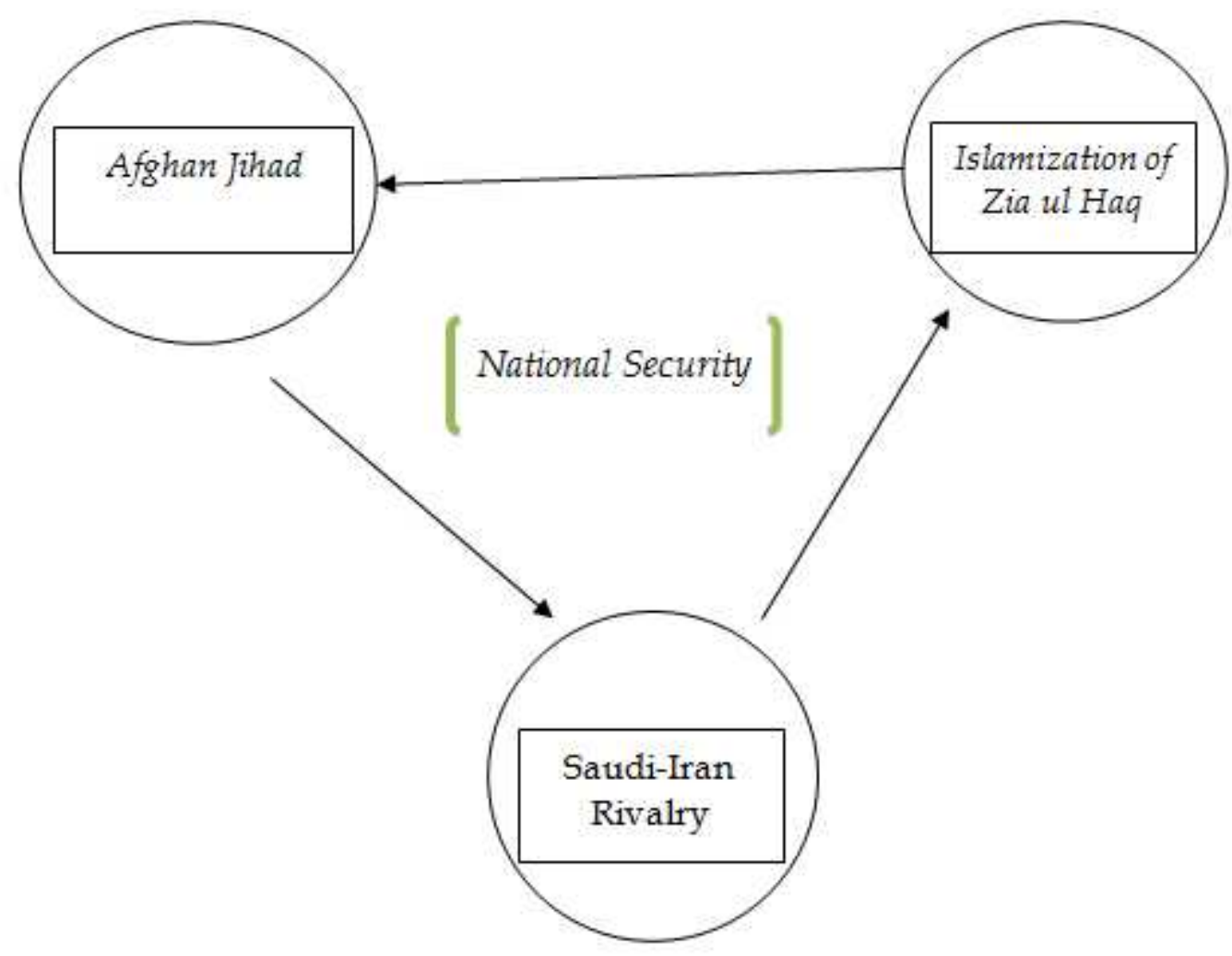

\section{Controversial Role of Madrassas: Breeds of Extremism and Terrorism}

Madrassa is an Arabic word which means "School" or "Learning institution". In Pakistan word Madrassa is translated as Religious Islamic School. Madrassa is source of education in Pakistan. Thousands of children get education from madrassa. Madrassa system is working before the Pakistan came into being. It is working before the British colonial period (Kaur, 1990). This educational system is not only providing religious knowledge but also develop manners, Intellectual skills, Ethics and a source of transfer's traditional values to next generation. In Pakistan Madrassa system runs mostly on charity basis. Mostly it provided free of cost education or may be charged very small amount of fee to their students. Every Madrassa had 
their own curriculum and examination system strictly follows specific sectarian split controlled by their own organizations or Boards (Ramzan \& Rabab, 2013). However Deoband (Wahhabi) Madrassas are greatly criticized as sanctuaries of terrorism and spreading extremism in Pakistani society.

At independence in 1947 Pakistan had only 245 madrassa's (Institute of Policy Studies, 2005).This figure dramatically increased during Zia-ul-Haq regime. Different reports and studies have shown different Madrassa statistics. According to the most authentic, and reliable source Ministry of Religious Affairs Pakistan estimated in April 2002 the total number of Madrassa functioning in Pakistan were over 10 thousand in which 1.7 million students were studying (International Crises Group, 29th July 2002). After 1979 when Pakistan indulged in long proxy war American policy makers and think tanks were actively shaping Pakistan's national policies. They need a generation of fighters who can serve their agenda against USSR. US administration and western NGOS were very actively supporting Jihadists and madrassa culture with dollars and arms to serve their own agenda. Madrassa not only helped to motivate young generation toward jihad but also successfully developed anticommunist Jihadist generation to serve External agenda (Fair C. C., Militant Recruitment in Pakistan: A New Look at the Militancy-Madrasah Connection, 2007).

At the end of Zia regime 8000 registered madaris and approximately over 25000 unregistered madarassas were working in Pakistan (Murphy \& Malik, 2009). During that period five thousand mosque schools were opened and entire curriculum of schools were modified with emphasis on jihad and Islamization program. At that time main objective of jihad was to counter communism. USA alone provided 5.1 million USAID to design and develop curriculum that promotes jihad. Over 13 million worth of text books and literature funded by US was distributed in Afghan refugee camps and schools (Ashraf, 2010).

These madrassas played a key role to develop extremist religious flavor in Pakistani society. Most of these Madarassas were preaching narrow version of Islamic teaching which were mostly based on or related to Wahabi version of Islam (Murphy \& Malik, 2009). Evolutionary process and role of madrasa on that particular period lead Pakistani society toward religious intolerance, sectarian violence and extremism.

\section{Outcomes of Jihadi Narrative}

Due to Jihadi Narrative built up in the country, Pakistan faced with many challenges that are serious to its National Security. Some of them are as follows.

\section{Afghan Refugees: a Potential Threat}

Afghanistan suffered with hundreds of Air and ground strikes by the Soviet forces during Afghan-Soviet war 1979. Soviet forces targeted civilian population with heavy bombing which forced Afghan refugee to flee into Pakistan. The largest 
migration took place after soviet invasion in 1979 in which approximately over 3.2 million Afghan refugees took asylum in Pakistan. This was almost one fourth of entire Afghan population. (Hilali, 2002) Pakistan welcomed these migrants in difficult period due to Muslim brother hood and ethnic affinity. Most of these people settled near Afghan border in camps and other places in two provinces of Pakistan adjacent to Afghan border in Khyber Pakhtunkhwa (KPK) and Baluchistan. They mixed up well with natives due to religious, cultural, and linguistic ties. These refugee camps also served as base camps for military training for jihad against Soviets with the help of western funding. Due to war situation in Afghanistan which continued for decade, these refugees stayed in Pakistan. In fact their growth reached to over 4 million at the end of 1986 (Mehrunnisa, 2001).

Most of the Afghan refugees were tolerated by Pakistani authorities to stay without any kind of documentation. Many Afghan refugees managed to earn by doing different small kinds of jobs in Pakistan including agriculture labor, salesman, venders, and construction workers in urban areas of Pakistan. Some of them established their own small businesses in urban areas. Pakistani authorities did not restrict them to camps and allow them to freely move in near cities of Pakistan to earn money for their families. They were free to travel anywhere in Pakistan and free to choose where they wish to live in Pakistan. They had no restriction to stay in camps as a result more than one millions refugees' spread in different cities of Pakistan (Grare \& Maley, 2011).

More over Pakistan Government had not fully control on Pak-Afghan border and also had little control over cross border movement. Furthermore the writ of Government over FATA area was also not sufficient to control all the activities. At the end of the Afghan-Soviet war, these people preferred to stay in Pakistan due to civil war and unstable security condition in Afghanistan. Some of these refuges involved in negative activities like smuggling, militancy and other criminal activities (Hilali, 2002). These refugees were also involved in smuggling of all kind of weapons and also involved in sectarian killing in Pakistan. In short due to less control of Government on border areas particularly in FATA helped to nurture criminal elements in that area which lead toward militancy and terrorism.

\section{Afghan Civil War}

Pakistan and Afghanistan being immediate neighbors shared geography, Ethnicity, religious, cultural and social ties but relations between the two countries have never been smooth. Pak-Afghan relations had experienced lot of ups and downs. Pakistan always desired to envision smooth and friendly relations with the Afghanistan. Peaceful, Secure and friendly North-Western border always remained a desire and security requirement for Pakistan.After the Soviet withdrawal Afghanistan experienced eight years of civil war. No central power was there to hold the control and integrate Afghanistan. Civil war had devastating implication on Afghanistan and its surroundings. Anarchy, chaotic conditions and civil war in Afghanistan had negative impact on Pakistan as well (Seth, 2009). 
Pakistan had to deal with different kinds of challenges to protect its sovereignty and national security. Intra-Afghan conflict which emerged into civil war confirmed that more than three million refugees were to remain in Pakistan. More over Pakistan desperately wanted peaceful and friendly relations with Afghanistan. Only peaceful and friendly Afghanistan can provide strategic depth and economic route to central Asian states. But at that time pro-communist Government in Kabul was opposing Pakistan and nurturing relation with India which was badly damaging Pakistan national Interest. To counter India and ProSoviet Government in Afghanistan, Pakistan again started to support Afghan Mujahedeen during civil war in Afghanistan. In this scenario, a new force called "Taliban" emerged amongst the mujahedeen after long civil war in Afghanistan. Taliban movement was started against the corruption and lawlessness situation in Afghanistan. The main purpose of the movement was to bring peace, integrate Afghanistan, disarm population and established the rule of law through Islamic Sharia (Yousufzai, 1995). Many scholars believe that Taliban movement basically originated from refugee madrassa students who were studying and living in Pakistan during Afghan-Soviet war (Ahmad R. , 1999). During Taliban movement, thousands of Pakistani students of Madrassa particularly adjacent to Afghan border move toward Afghanistan to join and backed the Taliban in 1997. Pakistani madrassa's in KPK and Baluchistan (adjacent to Afghan border) were closed for month to join the Taliban in battle for Mazar-e-Sharif (Hussain Z. , 2007). At that time US administration also felt that Taliban can play a positive role forthe integration of Afghanistan and can provide strong centralized Government in Afghanistan.

\section{Talibanization of Country}

Pakistan's support for Taliban was not essentially based on ideological basis. It was mainly based on geo-strategic approach aimed at friendly Afghanistan can provide strategic depth. Strategic depth theory was establishment assumption that Pashtun friendly Afghanistan can provide strategic depth to its security which not only secure its northern-west border but also guarantee of physical security of a country in case of any possible aggression from India. Taliban installation was celebrated as Afghanistan became a fifth province of Pakistan. But unfortunately this objective was not achieved because Taliban rejected all kind of dictations from Pakistan and was not willing to play as a client role (Hussain, 2007).

When Taliban came into power they perused policies which further led Afghanistan toward extremism and militancy. Foreign Arab richest Saudi recruiters Osama bin Laden Participated in Afghan jihad during 1979 to 1990. He went back to Saudi Arabia in 1990 after soviet withdrawal. When Taliban took control most part of Afghanistan he came back to Afghanistan in May 1996. His affiliation with Mullah Omer influenced the Taliban policies. Bin laden reorganized Arab militants with the aim of Global Jihad (Ahmad, 1999). 
The situation became deteriorated for Pakistan when Taliban's influence started affecting Pakistan tribal areas. Talibanization and militant culture was developed in Pakistan. Most of foreign jihadi organizations remained active in Pakistan. Most of militant elements whom were troupers during soviet war stayed there for long time even after the withdrawal of soviet forces. These groups were involved in civil war in Afghanistan and were fighting against Northern Alliance and also involved in different kind of ethnic, sectarian conflicts in both countries. Different militant groups were freely working and forming in Pak-Afghan border Areas without any fear. Nexuses of extremist and militant groups nurture in these areas during this period latter on involved in terrorist activities in Pakistan and started to challenge the writ of the government.

\section{Requisite for Counter Narrative}

After 9/11 International impression was built up assuming that Pakistan had very strong influence on Taliban as before this incident Pakistan was considered a staunch supporter of Taliban. But the reality was that Pakistan had not much influence on them as westerners might be thought. Pakistan's own security was at stark due to pro-Taliban policy. It was very clear that Pakistan failed to achieve its objectives through Afghan policy during that particular period because Pakistan was unable to get any support for Taliban from international community and also this policy added further problem to Pakistan in the form of militancy, Extremism, and Isolation in world community.

Now National Security dimension for Pakistan were intensely transformed toward rising internal security threats. Pakistan is facing serious internal challenges to its National Security in the form of Militancy and Terrorism. The nature of the threat ranges from multiple form of terrorism including militancy, extremism, sectarian violence to ethnic conflicts and separatism etc. Pakistan not only has to secure its eastern border but also has to cover its western border and has to deal with all kinds of internal threats. This has adversely affected Economic, political and Socio-culture of Pakistan. Every Pakistani citizen feels insecure as compared to previous decades. Today it can be arguably said that major threat to its National Security is from internal sources which are playing as a puppet in external hands (Chishti, 2014).

\section{Dynamic Contemporary Challenges to National Security}

Although Pakistan has overcome the security threats but still it faces challenges like political instability, economic crisis, unemployment, illiteracy, Kashmir issue, escalation on Line of Control, activation on eastern border, threat of FATF sanctions and Foreign Policy issues. 


\section{Political Instability}

Pakistan has faced four direct military rules since its inception. Due to these Martial Laws, democracy can never be strengthened in the country. It has always remained turbulent during different phases. Although there is continuity in the electoral process since 2002 and a civilian Government is replaced with another elected one but still the situation is chaotic. Opposition parties blame for rigging and political engineering in order to get specific results. This political unrest is hindering to create a stable situation in the country.

\section{Economic Crisis}

Although there is regional economic crisis that may affect the World globally like 2008. World is facing acute economic war between two rivals with giant economies. America and China are one to one with each other on the economic front for the last two years. Pakistan is also victim of this crisis. Its meager economy may not bear faults in the preceding years. Pakistan'smajor issue is Current Account deficit that is almost resolved. Still the other sectors of economy are stagnant which is to be healed.

\section{FATF Grey List}

Another contemporary grave issue is Financial Action Task Force (FATF) gray list issue. Pakistan is blamed to support terrorist activities around the World through its unregulated and un documented economy. Although Pakistan has done much in this regard to meet the demands by FATF, still the sword is hanging upon it.

\section{Kashmir Issue}

When Pakistan was handling its critical issues and managing its day to day debacles, India has created a new situation for Pakistan by revoking its Article 370 and 35A from its constitution. By altering these articles, the catastrophe in Indian Occupied Kashmir is mounted. Bilateral agreements between two countries are impaired by this one sided move.Until the Kashmir dispute is resolved between two countries, Pakistan will not be stable.

\section{Conclusion}

Militancy and extremism have become major challenges for Pakistan. The roots of Extremism and Militancy in Pakistan instigated due to many factors including Political instability in the country, Military regimes, and Pakistan's role in Afghan Jihad of 1979, Development of Madrassa, Injustice, and poor Socio-Economic conditions etc. These factors played an important role to spread extremism in Pakistani society. (Azam, 2014)The weak institutions of State and poor socioEconomic structure have provided space to grow extremism in Pakistani society. As a result different groups became more powerful and started challenging the writ of 
the state, and tried to impose their Extreme Ideologies to pursue their agenda by using violence and terrorism. Rise of militancy and Extremism is linked to recent and past history of the country. The militant culture started mounting for more than two decades. Zia-ul-Haq Military regime and policies adopted during that particular period played key role to nurture extremism and militant culture in the society. Pakistan's role during Afghan Jihad, influx of refugees, Iranian revolution and its effects on Pakistan, Iran-Saudi proxy war in the region, Madrassa culture, foreign funding and Pakistan support to Taliban regime negatively affected Pakistani Society(Sultan, 2006). 


\section{References}

Abbas, H. (2002). Pakistan drift into Extreamism. New York: Yale University press.

Abbas, H. (2005). Pakistan's Drift into Extremism: Allah, the Army and America's War on Terror. New Delhi: Pentagon Press.

Abbas, H. (2008). A Profile of Tehrik-i-Taliban Pakistan . The Combating Terrorism Center.

Abbas, Z. (2008, may 19). Taliban Ousted, But Spinkai Is Now a Ghost Town. Dawn News.

Abbasi, N. M. (2013). Impact of terrorism on Pakistan. Strategic Studies, 23, 33-68.

Abbasi, N. M. (2014). Impact of terrorism on Pakistan. Introduction of the Institute of Strategic Studies.

Ali, M. (2001). Readings in Pakistan's Foreign Policy, 1971-1998. Karachi: Oxford University Press.

(April 25, 2004, april 25). Dawn News. Retrieved from http:// www.dawn.com/news/393688/five-militants-pardoned-for-peacefullife-aliens-asked-to-surrender-by-30th

Ashraf, N. (2010). The Islamization of Pakistan"s Educational System: 1979-1989," cited in "The Islamization of Pakistan 1979-2009 A Special Edition of Viewpoints. The Middle East Iinstitute, Washington DC.

Azam, M. (2014). Genesis of Militancy in Pakistan. IPRI Journal XIV, no. 1.

Azam, M. (2014). Genesis of Militancy in Pakistan. IPRI Journal XIV, no. 1 (Winter 2014): 102-123.

Burke, S. M. (1973). Pakistan's Foreign Policy. london: University press, Ely, london.

Cheema, P. I. (2006). Pakistan-Afghanistan Relations. South Asian Journal, 96-112.

Chishti, N. A. (2014). Pakistan's National Security: An Analytical Study. J. Asian Dev. Stud, Vol. 3, Issue 3, .

Fair, C. C. ( 2007). Militant Recruitment in Pakistan: A New Look at the MilitancyMadrasah Connection. Asia Policy, Number 4 (July 2007).

Grare, F., \& Maley, W. (2011). The Afghan Refugees in Pakistan. Middle East Institute.

Hilali, A. Z. (2002). Cost \& Benifits of Afghan war for Pakistan cited in. Contemprary south asia. 
Hillary Clinton: 'It Would Be a Mistake' to Walk Away from Pakistan. (2010, July 19). Retrieved from Fox News: http://www.foxnews.com/on-air/on-therecord/transcript/hillary-clinton-039it-would-be-mistake039-walk-awaypakistan

Hussain, S. (2004). War against terrorism, Pakistani perspective. . IPRI Journal,.

Hussain, T. (2005). U.S.-Pakistan Engagement :The War on Terrorism and Beyond. Washington : United States Institute Of Peace.

Hussain, Z. (2007). Frontline Pakistan: The Struggle with Militant Islam. New York:London: Published in 2007 by I.B.Tauris \& Co Ltd.

Javaid, U., \& Fatima, Q. (2013). An Analytical Study of Pakistan's Policy Toward Afghanistan Before the Taliban's Rise. Journal of Political Studies, Vol. 20, Issue - 2, 2013, 59:89.

Kaur, K. (1990). Madrasa Education in India: A survey of its Past and Present. Center for Research in Rural and Industrial Development.

Khalid, I. (2014). Topology of Extremism: Implication on the Contemporary Politics of Pakistan. A Research Journal of South Asian Studies Vol. 29, No.12, 23-39.

Malik, H. (2008). US Relations with Afghanistan and Pakistan. Karachi: Oxford Press.

Malik, I. H. (2008). The history of Pakistan. Westport, Connecticut, London: Greenwood Press.

Mehrunnisa Ali. (2001). Readings in Pakistan Foreign Policy 1971-1998 . New York: Oxford University Press.

Miller, S. E. (2001). International Security at Twenty-five: From One World to Another. International Security, Vol. 26, No. 1.

Murphy, D. E., \& Malik, D. A. (2009). PAKISTAN JIHAD: THE MAKING OF RELIGIOUS TERRORISM. IPRI Journal IX, no.2, 17-31.

Murphy, E. (2014). The Making of Terrorism in Pakistan: Historical and Social Roots of Extremism. IPRI Journal XIV, no. 1 (Winter 2014): 124-146, 164.

Paleri, P. (2008). National Security: Imperatives and Challanges. New Delhi: Tata McGraw-Hill Publishing Company Limitted.

Ramzan, D. S., \& Rabab, A. (2013). Madrassa Education in the Sub-ContinentMyths and Realities. Al-Idah 27. 
Rizvi, H. A. (2006). Pakistan's Foreign Policy:An Overview1947-2004. Pakistan Intitute of Legislative development and Transparency(Pildat).

Romm, J. J. (1993). Defining National Security: The Nonmillitary Aspect. New York: Council Of Foreign Relations press.

Seth, J. (2009). In the Graveyard of Empires. New York: W.W.Norton \& Company.

Sultan, M. G. (2006). Pakistan's Struggle against Terrorism. Pakistan Defiance Review20 summer: 6. Title 22 of the United States Code, Section $2656 f(d)$.

Sultana, S. (2012). Pakistan: The Critical Battlefield of War on Terrorism. Pakistan Journal of Social Sciences (PJSS) Vol. 32, No. 1 (June 2012),, 49-63.

Weinbaum, M. G. (1991). WAR AND PEACE IN AFGHANISTAN:THE PAKISTANI ROLE. Middle East Journal, Vol. 45, No. 1 (Winter, 1991), , 71-85.

Weinbaum, M. G. (1994). Pakistan and Afghanistan: Resistance and Reconstruction. Boulders.

Yousufzai, R. (1995, febrary 07). Here comes the Taliban. Newsline, .

Yusafzai, \& Iqbal, H. (2011). The US Factor in Pak-Afghan Relation post 9/11. Lambert Academic Publishing (LAP) gMB ECo.KG Germany.

Yusafzai, R., \& Mahsud, S. (2004, march 18 ). Waziristan clashes death toll rises. The News.

Yusufazi, R. (2007, january 19). Putting out the fire in Waziristan. The News.

Yusufzai, A. (2012, january 17). Pakistan's forests fall victim to the Taliban. The Guardian .

Yusufzai, R. (2002, june 07). Fall of the Last Frontier? Retrieved from newslinemagazine: http://www.newslinemagazine.com/2002/06/fall-of-thelast-frontier/ 